\title{
Molecular diversity and functional variability of environmental isolates of Bacillus species
}

\author{
Ajay Kumar ${ }^{1 *}$, Amit Kumar ${ }^{2}$ and Amit Pratush ${ }^{3}$
}

\begin{abstract}
In the present study, out of 264 phosphate (P) solubilizing Bacillus strains isolated from apple rhizosphere, only twelve isolates were found to be efficient (showed most of the plant growth promoting activity) which were further characterized at molecular level using 165 rDNA partial gene sequencing. Out of 12 isolates, MZPSB 207 was found to be most efficient P-solubilizing $(864.71 \mu \mathrm{g} / \mathrm{ml})$ isolate which also showed indole acetic acid production $(51.83 \mu \mathrm{g} / \mathrm{ml})$, siderophore production, ammonia production, antagonistic property (against Rhizoctonia solani and Fusarium oxysporum), hydrolytic enzymes productions (protease, chitinase and cellulase), 1-aminocyclopropane-1-carboxylate (ACC) deaminase production $\left(7.7 \mu \mathrm{m} \mathrm{aKB} \mathrm{mg}{ }^{-1} \mathrm{~h}^{-1}\right)$. The in-vitro seed germination assay showed that Bacillus (twelve isolates) inoculated seeds showed more seed germination and seedling vigor rate as compared to uninoculated control treatment. For the genetic diversity studies of efficient 12 strains, the polyphasic approach using 16S-rDNA, Repetitive element sequence (rep) based PCR (ERIC-PCR and BOX-PCR) were used. Based on 165 rDNA partial gene sequencing the isolated Bacillus genus was divide into four groups. First group (five isolates), second group (two isolates), third group (three isolates) and fourth group (two isolates) which showed close genetic relatedness to the B. subtilis, B. pumulis, B. megaterium and B. amyloliquefaciens, respectively. The rep PCR fingerprinting showed variability between and within the species. The large variability was showed by ERIC-PCR whereas some variability was showed by BOX-PCR. The results clearly showed that 165 rRNA gene sequencing is unable to discriminate the isolates at strain level. But rep-PCR fingerprinting is excellent tool to characterize and discriminate the strains at the genomic level.
\end{abstract}

Keywords: ACC deaminase; Bacillus genetic diversity; Plant growth promoting activity; Rep PCR fingerprinting; 16S rDNA; Seed germination

\section{Background}

Bacillus is one of the genetically diverse, spore forming, gram positive bacteria (Bhandari et al. 2013). It is widely distributed in various ecological niches and commonly isolated strain. This genus has wide applications.

Bacillus has variety of roles in ecology, biotechnology, industry as well as in clinical microbiology, so the various genetic diversity studies on this particular genus have been made. Some species shows same morphological and biochemical features due to this it is still very difficult to characterize new isolates (Harrel et al. 1995), which makes it hard to separate them. Beside this, the environmental isolates of Bacillus showed variability in its physiological, nutritional requirements and its genetic

\footnotetext{
* Correspondence: ajaysamkria@gmail.com

'Department of Microbiology, Shoolini Institute of Life Sciences and Business Management, Solan, Himachal Pradesh 173212, India

Full list of author information is available at the end of the article
}

content. Increasingly molecular techniques are used for quick species identification. For comparative study and to discriminate the genomes of bacteria various molecular techniques are used like $16 \mathrm{~S}$ rRNA gene sequencing, Repetitive element sequence-based PCR (rep-PCR). The rep-PCR fingerprinting is found to be very useful molecular technique to discriminate between the species, as this fingerprinting use various DNA segments present in the bacterial genome (Ishii and Sadowsky 2009).

Bacillus isolates originating from different sources have been studied, but in the rhizosphere huge microbial diversity is present. The bacteria in the rhizosphere help in the plant growth by using various mechanisms and that is why these bacteria are known as plant growthpromoting rhizobacteria (PGPR) (Farina et al. 2012). Phosphorus is an essential mineral nutrient that often limits plant growth because of its low solubility and fixation in the soil. Under poor available phosphorus soils, 
phosphate-solubilizing microorganisms play an important role in solubilization of insoluble phosphates and make it available to plants in soluble form which ultimately increases the plant growth (Tripura et al. 2007).

Due to spore forming capability Bacillus is one of the most important genera among PGPR which help in the formation of stable bioinocluant. Various environmental factors generate stress that affects the activity or potential of the local micro-flora (Vriezen et al. 2006). Therefore, study of phosphate-solubilizing Bacillus under stress conditions from the rhizosphere is the key area to screen new strains that has immense potential to be used as bioinoculant in the agriculture. Bacillus species are known already to be as phosphate solubilizers but scanty of reports are available on the potential of phosphate solubilizer under stress conditions. As well as it is well documented in the literature that changing in the ecological niche or geographical region there is definite genetic variability at genus level, species level etc. But, it is interesting to study whether there is genetic variability occurs at genus level or species level from the same ecological niche or not? Therefore, present study was designed to explore the culturable Bacillus diversity in the rhizosphere of apple with the help of molecular tools and to characterize these isolates with respect to plant growth promoting traits.

\section{Results and discussion}

\section{Isolation and screening of P-solubilizer Bacillus isolates}

In the rhizosphere root exudation play an important role in defining the functional communities and diversity which varies with plant species. In the rhizosphere these microbial communities have beneficial, neutral or detrimental interaction with plant roots and therefore influence the plant growth (Bakker et al. 2013; Zelicourt et al. 2013). From the huge diversity in the rhizosphere, Bacillus is frequently isolated from rhizosphere which generally influences the plant growth positively.

After nitrogen, phosphorus is second major nutrient required for the plant growth. Generally, plenty of phosphorus is available in the soil but it is in the fixed form (insoluble mineral form). So, to overcome the deficiency of phosphorus, farmers generally used phosphatic fertilizers but unfortunately most of the applied fertilizer is fixed in the soil in the form of $\mathrm{Al} / \mathrm{Fe}$ phosphate in acidic soils and as a calcium phosphate in the alkaline soils (Bashan et al. 2013; Sharma et al. 2013). Therefore, there is need to convert this non-available form of phosphorus to the available form by some cheap and ecological sound method. Under such condition phosphate $(\mathrm{P})$ solubilizers play an important role in providing usable form of $\mathrm{P}$ to the plants without affecting the soil health.

Keeping all this in view, a total of 264 phosphate solubilizing Bacillus strains were isolated in the present study from Malus domestica rhizosphere which showed clear halo zones around the colony. The size of zone of solubilization varies between 3 to $29 \mathrm{~mm}$ on Pikovskaya (PVK) agar medium containing TCP (tricalcium phospahte). Out of 264 isolates only twelve were found to show clear and greater than $10 \mathrm{~mm}$ zone of solubilization. So, these 12 isolates were selected for further study. As earlier literature shows that TCP alone is not excellent criterion for the selection of P-solubilizer as the isolate may or may not shows P-solubilization on $\mathrm{Al} / \mathrm{Fe}$ phosphate or calcium phosphate (hydroxyapatite, brushite etc.) therefore, these 12 isolates were tested for P-solubilization in a plate containing Al-P, Fe-P and hydroxyapatite separately. Except for isolates MBPSB5, MBPSB37 and MBPSB69, all other isolates showed zone of solubilization on three tested insoluble phosphate source but it was less as compared to TCP. It was also observed that zone of solubilization in hydroxyapatite plates were less as compared to Al-P and Fe-P.

As the direct measurement of phosphate solubilization in broth assay is likely to give more reliable results than a regular plate assay, the screened 12 phosphate-solubilizing strains were further tested for their ability to solubilize TCP in NBRIP broth (Table 1). The seven isolates showed maximum solubilization on the $7^{\text {th }}$ day of incubation and their maximum values of $\mathrm{P}$ solubilized varied from 263.71 to $825.03 \mu \mathrm{g} \mathrm{P} / \mathrm{ml}$ (Table 1). Five isolates showed maximum solubilization on $5^{\text {th }}$ day of incubation and their values varied from $221.63 \mu \mathrm{g} \mathrm{P} / \mathrm{ml}$ to $864.71 \mu \mathrm{g} \mathrm{P} / \mathrm{ml}$. After reaching maximum value of solubilization, in most of the isolates (irrespective of the day of maximum solubilization) the solubilization decreased thereafter and continued upto $11^{\text {th }}$ day. The isolate MBPSB 207 was found to be most efficient phosphate solubilizer which showed $864.71 \mu \mathrm{g} \mathrm{P} / \mathrm{ml}$ of phosphate solubilization which was statistically higher than the other tested isolates. In case of other source of phosphorus (Al-P, Fe-P and hydroxyapatite) tested, there was less $\mathrm{P}$-solubilization as compared to TCP with maximum activity of $529.47 \mu \mathrm{g} \mathrm{P} / \mathrm{ml}$ in Fe-P, $396.58 \mu \mathrm{g} \mathrm{P} / \mathrm{ml}$ in Al-P and $142.73 \mu \mathrm{g} \mathrm{P} / \mathrm{ml}$ in Ca-P was showed by the isolate MBPSB 207. The reason for this may be the low solubility of these stable minerals phosphates as compared to the TCP (Sulbaran et al. 2009; Bashan et al. 2013).

After reaching maximum value of solubilization, in most of the isolates (irrespective of the day of maximum solubilization) the solubilization decreased thereafter and continued upto $13^{\text {th }}$ day. The reason for this trend may be attributed to the fact that when the rate of uptake is higher than that of solubilization, a decrease in $\mathrm{P}$ concentration in the medium could be observed. On the contrary, when the uptake rate decreases, the level of $\mathrm{P}$ in the medium increases (Rodriguez and Fraga 1999).

The $\mathrm{pH}$ of the growth medium changed during the process of solubilization from its initial value of 7.0 to 3.89 in majority of the isolates. The isolate MBPSB 207 
Table 1 Quantitative assay of phosphate solubilization and pH changes exhibited by different Bacillus isolates in NBRIP broth

\begin{tabular}{|c|c|c|c|c|c|c|c|c|c|c|}
\hline \multirow[b]{3}{*}{ Isolate } & \multicolumn{4}{|c|}{ Phosphate solubilization ( $\mu \mathrm{g} / \mathrm{ml}$ ) } & \multirow[b]{3}{*}{ Mean } & \multicolumn{5}{|c|}{$\mathrm{pH}$ of medium } \\
\hline & \multicolumn{4}{|c|}{ Days of incubation } & & \multicolumn{5}{|c|}{ Days of incubation } \\
\hline & 3 & 5 & 7 & 11 & & 3 & 5 & 7 & 11 & Mean \\
\hline MBPSB 5 & 262.76 & 411.69 & 508.41 & 358.36 & 385.30 & 6.71 & 5.48 & 5.35 & 5.03 & 5.64 \\
\hline MBPSB 12 & 341.69 & 572.02 & 416.38 & 341.22 & 417.83 & 6.19 & 5.62 & 4.93 & 5.38 & 5.53 \\
\hline MBPSB 29 & 329.41 & 607.53 & 738.02 & 585.92 & 565.22 & 6.52 & 5.07 & 4.51 & 3.89 & 4.99 \\
\hline MBPSB 37 & 194.17 & 297.52 & 481.27 & 313.52 & 321.62 & 6.28 & 5.43 & 5.72 & 4.96 & 5.60 \\
\hline MBPSB 69 & 157.34 & 221.63 & 263.71 & 198.37 & 210.26 & 5.84 & 4.96 & 4.21 & 3.92 & 4.73 \\
\hline MBPSB 124 & 398.25 & 806.12 & 664.49 & 407.36 & 569.05 & 6.58 & 5.54 & 5.76 & 6.15 & 6.00 \\
\hline MBPSB 147 & 291.47 & 572.59 & 825.03 & 576.35 & 566.36 & 6.47 & 5.35 & 4.69 & 4.84 & 5.34 \\
\hline MBPSB 164 & 236.43 & 519.78 & 452.64 & 305.72 & 378.64 & 5.92 & 5.19 & 5.32 & 4.97 & 5.35 \\
\hline MBPSB 194 & 216.79 & 380.03 & 647.84 & 473.16 & 429.45 & 6.03 & 6.12 & 5.44 & 4.89 & 5.62 \\
\hline MBPSB 207 & 426.37 & 864.71 & 725.61 & 591.04 & 651.93 & 6.39 & 5.21 & 4.85 & 4.21 & 5.41 \\
\hline MBPSB 219 & 204.23 & 415.85 & 613.37 & 483.51 & 429.24 & 6.14 & 5.05 & 5.57 & 4.73 & 5.37 \\
\hline MBPSB 259 & 424.74 & 529.16 & 437.58 & 262.03 & 367.88 & 5.88 & 5.07 & 4.63 & 4.85 & 5.11 \\
\hline Mean & 275.13 & 516.55 & 564.53 & 408.05 & & 6.24 & 5.34 & 5.08 & 4.82 & \\
\hline Variant & SEm \pm & $C D(P \leq 0.01)$ & & & & SEm \pm & $C D(P \leq 0.01)$ & & & \\
\hline Isolate & 0.214 & 0.937 & & & & 0.064 & 0.273 & & & \\
\hline Day & 0.081 & 0.348 & & & & 0.026 & 0.091 & & & \\
\hline Interaction & 0.526 & 1.563 & & & & 0.159 & 0.384 & & & \\
\hline
\end{tabular}

showed a maximum solubilization of $864.71 \mu \mathrm{g} \mathrm{P} / \mathrm{ml}$ at $\mathrm{pH}$ of 5.21 on $5^{\text {th }}$ day of incubation. In the present study, no relationship could be ascertained with the quantity of P-solubilized and value of $\mathrm{pH}$.

\section{Screening of isolates for plant growth promoting activities}

One of the direct mechanisms by which PGPR promote plant growth is by the production of phytohormones as well as siderophores (Glick 1995). Out of 12 strains of phosphate solubilizer, ten, eleven and twelve isolates were found to produce siderophore, ammonia and indole-acetic acid (IAA), respectively (Table 2). MBPSB 207, the most efficient isolate with respect to phosphate solubilizing activity, showed $51.83 \mu \mathrm{g} / \mathrm{ml}$ of IAA production which was significantly higher than the other strains except for isolate MBPSB 37. Auxins (IAA and derivatives) are responsible for division, extension, and differentiation of plant cells and tissues (Mano and Nemoto 2012; Duca et al. 2014). In microorganisms various known pathways of IAA biosynthesis are find out which may be tryptophan dependent or independent (Tsavkelova et al. 2006; Duca et al. 2014). In the present study medium was amended with tryptophan (5 mM) which act as a precursor for the biosynthesis of IAA. In natural condition the tryptophan may be available in the rhizosphere through root exudates as noticed by the Beniziri et al. (1998).
The isolate MBPSB 207 was also found positive for siderophore and ammonia production. Siderophores are low molecular weight iron chelating ligands synthesized by microorganisms. Microbial siderophore may stimulate plant growth directly by increasing the availability of iron in the soil surrounding the roots or indirectly by competitively inhibiting the growth of plant pathogens by scavenging iron and making it less available to the pathogens (Fgaier and Eberl 2011). Similarly, ammonia is considered as one of the plant growth promoting metabolites and some authors considered the production of ammonia to be involved in antagonistic interaction that results in disease control (Saraf et al. 2011). Nevertheless, meticulous experimentation is required to exactly pin point the role of ammonia in plant growth and disease suppression.

Beside biostimulators, some PGPR are also reported to act as a bioprotectants and inhibit the fungal growth therefore in the present study 12 efficient isolates were tested for antifungal activity (Table 2). Twelve isolates except for isolate MBPSB 29 and MBPSB 164, were found to inhibit the growth of phytopathogenic fungus i.e. Fusarium oxysporum and Rhizoctonia solani. The most efficient isolate MBPSB 207 with respect to phosphate solubilization, showed more zone of inhibition as compared to the other isolates. Further, these twelve isolates were tested for the production of hydrolytic enzymes (Table 2). These enzymes are thought to play a 
Table 2 Bacillus isolates showed various plant growth promoting traits

\begin{tabular}{|c|c|c|c|c|c|c|c|c|c|}
\hline \multirow[t]{2}{*}{ Isolate } & \multirow{2}{*}{$\begin{array}{c}\text { IAA } \\
(\mu \mathrm{g} / \mathrm{ml})\end{array}$} & \multirow[t]{2}{*}{ Siderophore } & \multirow[t]{2}{*}{ Ammonia } & \multirow[t]{2}{*}{ Protease } & \multirow[t]{2}{*}{ Chitinase } & \multirow[t]{2}{*}{ Cellulase } & \multirow{2}{*}{$\begin{array}{c}\text { ACC deaminase } \\
\left(\mu \mathrm{m} \mathrm{aKB}^{-1} \mathrm{mg}^{-1} \mathrm{~h}^{-1}\right)\end{array}$} & \multicolumn{2}{|c|}{ Antifungal activity } \\
\hline & & & & & & & & $\begin{array}{c}\text { Rhizoctonia } \\
\text { solani }\end{array}$ & $\begin{array}{c}\text { Fusarium } \\
\text { oxysporum }\end{array}$ \\
\hline MBPSB 5 & $17.12 \pm 1.9$ & ++ & +++ & + & ++ & ++ & $5.8 \pm 0.5$ & ++ & + \\
\hline MBPSB 12 & $21.94 \pm 2.1$ & ++ & + & + & ++ & - & $8.1 \pm 0.8$ & + & +++ \\
\hline MBPSB 29 & $19.36 \pm 2.0$ & ++ & + & + & +++ & - & $1.5 \pm 0.1$ & - & - \\
\hline MBPSB 37 & $53.61 \pm 4.7$ & + & ++ & - & + & ++ & $4.8 \pm 0.3$ & + & + \\
\hline MBPSB 69 & $27.47 \pm 2.8$ & - & +++ & + & + & ++ & $8.6 \pm 0.7$ & + & ++ \\
\hline MBPSB 124 & $35.68 \pm 3.3$ & + & ++ & + & + & - & $7.4 \pm 0.5$ & + & + \\
\hline MBPSB 147 & $15.72 \pm 1.8$ & ++ & ++ & +++ & - & - & $6.5 \pm 0.4$ & +++ & ++ \\
\hline MBPSB 164 & $31.97 \pm 3.0$ & +++ & - & - & - & + & - & - & - \\
\hline MBPSB 194 & $46.84 \pm 4.1$ & + & ++ & - & ++ & ++ & $5.2 \pm 0.5$ & ++ & + \\
\hline MBPSB 207 & $51.83 \pm 4.2$ & ++ & +++ & ++ & ++ & +++ & $7.7 \pm 0.6$ & +++ & +++ \\
\hline MBPSB 219 & $22.39 \pm 2.1$ & - & ++ & + & + & - & $1.1 \pm 0.1$ & + & + \\
\hline MBPSB 259 & $38.73 \pm 3.6$ & +++ & + & ++ & + & +++ & $0.7 \pm 0.04$ & + & + \\
\hline
\end{tabular}

role in antifungal activity (Krakova et al. 2012). Out of twelve isolates 9, 10 and 7 strains were showed protease, chitinase and cellulase production, respectively. The strains MBPSB 147 showed highest protease activity, isolate MBPSB 29 showed highest chitinase activity whereas, isolates MBPSB 207 and MBPSB 259 showed highest cellulose activity. The isolate MBPSB 207 was found to show all the three enzyme activities. Beside these hydrolytic enzymes as antifungal molecules, IAA, siderophores and ammonia are also thought to involve in antifungal activity. IAA in combination with glutathione-s-transferases inhibits the spore germination and filament growth of fungus (Hahn and Strittmatter 1994). Whereas, siderophores indirectly showed antifungal activity by competitively inhibiting the growth of plant pathogens by scavenging iron and making it less available to the pathogens (Fgaier and Eberl 2011). The production of ammonia involved in antagonistic interaction and therefore acts as bioprotectant (Saraf et al. 2011) however, meticulous experimentation is required to exactly pin point the role of ammonia in suppressing the diseases.

Another important attribute as a PGPR is the production of ACC deaminase enzyme which lowers the ethylene levels and thus helps in the germination of seed and elongation of root (Belimov et al. 2001, Glick 2014). In the present work the highest ACC deaminase activity (Table 2) was showed by isolate MBPSB $69\left(8.6 \mu \mathrm{m} \alpha \mathrm{KB} \mathrm{mg}^{-1} \mathrm{~h}^{-1}\right)$ which was at par with isolate MBPSB $12\left(8.1 \mu \mathrm{m} \alpha \mathrm{KB} \mathrm{mg}^{-1} \mathrm{~h}^{-1}\right)$. The most efficient isolate MBPSB 207 showed $7.7 \mu \mathrm{m}$ $\alpha \mathrm{KB} \mathrm{mg}^{-1} \mathrm{~h}^{-1}$ ACC deaminase activity, which was significantly lower than isolate MBPSB 69.

The isolate MBPSB 207 yielded a 729-bp DNA fragment by use of the specific primer pair. Gene sequencing and BLASTN analysis confirmed the presence of acdS gene in representative MBPSB 207 strain associated with Malus tree. The acdS gene of isolate MBPSB 207 showed 96\% similarity with Klebsiella pneumoniae (JN625725), followed by 96\% similarity with Pseudomonas putida (HM053973). The occurrence and expression of acdS gene in this isolate suggested that this isolate possess the potential for improving plant growth.

\section{Seed germination assay}

The seeds are the reproductive units which are expected to give rise the healthy plant. During seed germination there are many morphological and physiological changes occurs, which activate the embryo and many factors influences the seed germination like temperature, moisture, hormones, enzymes etc. (Miransari and Smith 2014). In the present study, the effect of 12 efficient P-solubilizing strains on seed germination and vigor index is shown in Figure 1. The results clearly showed that the highest seed vigor index was noticed in case of isolate MBPSB 207 (998) followed by the isolate MBPSB 29 (941). All the isolates showed higher seed germination rate as compared to the control (uninoculated seeds). The highest seed germination rate (98\%) was showed by four isolates i.e. MBPSB 29, MBPSB 147, MBPSB 207 and MBPSB 219. These results were similar to the research report as given by the earlier worker (Mia et al. 2012). The increased rate of seed germination and seedling vigor in PGPR treated seeds as compared to control may be due to the release of various growth hormones like IAA, cytokinins, gibberellins etc. (Hayat et al. 2010). The gibberellins are involved in inducing the genes which help in the secretion of various enzymes like protease, nuclease, and hydrolases especially $\alpha$-amylase which are involved in assimilation and hydrolysis of starch that ultimately leads to higher seed germination rate (Gholami et al. 2009; Miransari and Smith 2014). The rate of seed germination also influenced by IAA which interact and 


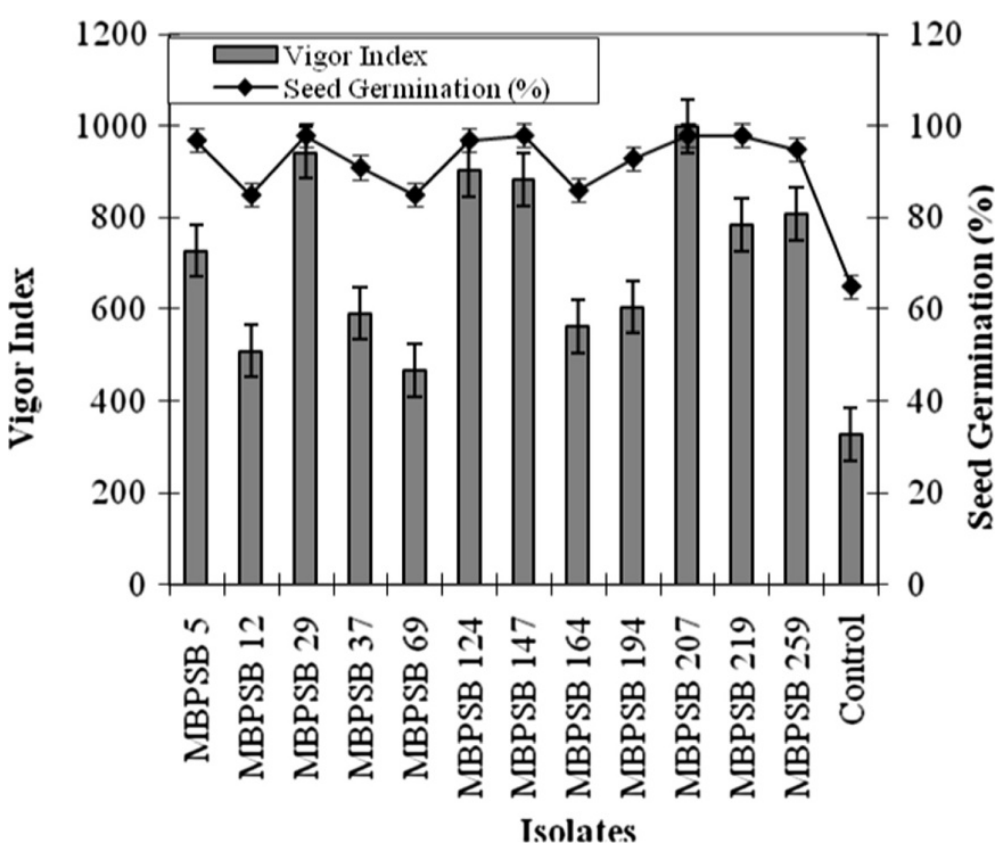

Figure 1 Seed germination and vigor index of maize seeds inoculated with efficient phosphate solubilizing bacterial isolates.

cross talk with gibberellins and ethylene. Also IAA up regulates the enzyme glyoxalase I which enhance the cell growth and development (Miransari and Smith 2014). Cytokinins help in increase seed germination by helping in to overcome the stresses like draught, salinity, oxidative etc. (Peleg and Blumwald 2011; Miransari and Smith 2014).

\section{Biochemical and molecular characterization}

The 12 efficient strains were characterized on the basis of their morphological and biochemical characteristics (Table 3). All the strains were gram positive, rods, motile, hydrolysis starch except for strains MBPSB 12 and MBPSB 147. Only one strain (MBPSB 194) was able to produce $\mathrm{H}_{2} \mathrm{~S}$. The other biochemical parameters are presented in Table 3.

To further confirm the results of biochemical analysis, the 16S rDNA gene sequence analysis was carried out. Their phylogenetic allocation and $16 \mathrm{~S}$ rRNA gene sequence identities are presented in Figure 2. All the strains according to similarity values (98\%) indicated that these all belong to genus Bacillus viz. B. amyloliquefaciens (MBPSB 29 and MBPSB 164), B. megaterium (MBPSB 69, MBPSB124 and MBPSB 219), B. pumilus (MBPSB 12 and MBPSB 147) and B. subtilis (MBPSB 5, MBPSB 37, MBPSB 194, MBPSB 207 and MBPSB 259).

Since, the efficiency of $16 \mathrm{~S}$ rRNA gene sequences are often limited for the identification of bacteria at species or strain levels, therefore DNA fingerprint methods have been developed to characterize and discriminate Bacillus strains (Weisburg et al. 1991; Janda and Abbott 2007). Therefore, to distinguish variability between and within bacterial strains a polyphasic genotypic fingerprinting tools i.e. ERIC and BOX-PCR were used in the present work (Figure 3). A number of bands were generated in the present study by all the twelve strains using ERIC and BOX-PCR which shows polymorphism in band pattern [Figure 3A and 3B (Lane 1: MBPSB 5, Lane 2: MBPSB 37, Lane3: MBPSB 194, Lane 4: MBPSB 207, Lane 5: MBPSB 259, Lane 6: MBPSB 12, Lane 7: MBPSB 147, Lane 8: MBPSB 29, Lane 9: MBPSB 164, Lane 10: MBPSB 69, Lane 11: MBPSB 124 and Lane 12: MBPSB 219 )]. One hundred and thirty three bands were observed by BOX-PCR (300-4200 bp) and 99 bands by ERIC-PCR (292-1605 bp). Bands pattern generated by ERIC-PCR showed large variability in all the tested 12 isolates as shown in Figure 3. Similarly, bands generated by BOX-PCR were also showed some variability for example in B. subtilis group except for isolate MBPSB 194 all the other four isolates (MBPSB 5, MBPSB 37, MBPSB 207 and MBPSB 259) showed similar bands pattern (Figure 3). In case of B. megaterium group (MBPSB 69, MBPSB124 and MBPSB 219) isolate MBPSB124 showed different band pattern. Whereas, B. pumilus group (MBPSB 12 and MBPSB 147) and B. amyloliquefaciens group (MBPSB 29 and MBPSB 164) showed same bands pattern.

The characteristic feature of repetitive sequences (ERIC and $\mathrm{BOX}$ ) is that they contain repetitive, non-coding sequences which are distributed through out the genome in a unique fashion and that help in discriminating the bacteria (Chudzik and Stosik 2005). The BOX element (154 bp) have three subunits i.e. BOX A, BOX B and BOX C of 
Table 3 Characterization of Bacillus strains obtained from the apple rhizosphere

\begin{tabular}{|c|c|c|c|c|c|c|c|c|c|c|c|c|}
\hline \multicolumn{13}{|c|}{ Bacillus strains } \\
\hline Characteristics & $\begin{array}{l}\text { MBPSB } \\
5\end{array}$ & $\begin{array}{l}\text { MBPSB } \\
12\end{array}$ & $\begin{array}{l}\text { MBPSB } \\
29\end{array}$ & $\begin{array}{c}\text { MBPSB } \\
37\end{array}$ & $\begin{array}{l}\text { MBPSB } \\
69\end{array}$ & $\begin{array}{c}\text { MBPSB } \\
124\end{array}$ & $\begin{array}{c}\text { MBPSB } \\
147\end{array}$ & $\begin{array}{c}\text { MBPSB } \\
164\end{array}$ & $\begin{array}{c}\text { MBPSB } \\
194\end{array}$ & $\begin{array}{c}\text { MBPSB } \\
207\end{array}$ & $\begin{array}{c}\text { MBPSB } \\
219\end{array}$ & $\begin{array}{c}\text { MBPSB } \\
259\end{array}$ \\
\hline Endospore & + & + & + & + & + & + & + & + & + & + & + & + \\
\hline Colony color & White & White & White & White & White & Off-white & White & White & White & White & White & White \\
\hline Pigmentation & - & - & - & - & - & - & - & - & - & - & - & - \\
\hline Motility & + & + & + & + & + & + & + & + & + & + & + & + \\
\hline $\begin{array}{c}\text { Starch } \\
\text { hydrolysis }\end{array}$ & + & - & + & + & + & + & + & + & + & + & + & + \\
\hline $\begin{array}{c}\text { Gelatine } \\
\text { hydrolysis }\end{array}$ & + & + & + & + & + & + & + & + & + & + & + & + \\
\hline $\mathrm{H}_{2} \mathrm{~S}$ production & - & - & - & - & - & - & - & - & + & - & - & - \\
\hline $\begin{array}{c}\text { Glucose } \\
\text { fermentation }\end{array}$ & + & + & + & + & + & + & + & + & + & + & + & + \\
\hline \multicolumn{13}{|c|}{ Biochemical parameters } \\
\hline Catalase & + & + & + & + & + & + & + & + & + & + & + & + \\
\hline Oxidase & + & + & + & + & + & + & + & + & + & + & + & + \\
\hline Indol & - & - & - & + & - & - & - & - & - & - & - & + \\
\hline VP test & + & + & + & - & - & - & + & + & - & + & - & + \\
\hline Citrate & + & + & + & + & + & + & + & + & - & - & + & - \\
\hline $\begin{array}{l}\text { Nitrate } \\
\text { reduction }\end{array}$ & - & - & + & + & + & - & - & + & - & + & - & + \\
\hline Urease & - & + & - & + & + & + & + & - & - & + & + & + \\
\hline
\end{tabular}

which BOX A is more conserved, whereas ERIC sequence (124-127 bp) has central, conserved palindromic sequence and therefore these conserved parts are used as a target in molecular biology for discrimination of bacterial species (Versalovic et al. 1994; Rademaker et al. 2005). On amplification of these repetitive sequences they yield a unique band patterns that serve as unique identifier (Versalovic et al. 1998). Also, these polyphasic genotypic fingerprinting techniques are excellent and reliable tools as compared to 16S rRNA gene sequences for discriminating the environmental Bacillus isolates as a separate group (Kim et al. 2003; Patil et al. 2010). The results clearly showed that $16 \mathrm{~S}$ rRNA gene sequencing is unable to discriminate the isolates at strain level. But rep-PCR fingerprinting (ERIC and

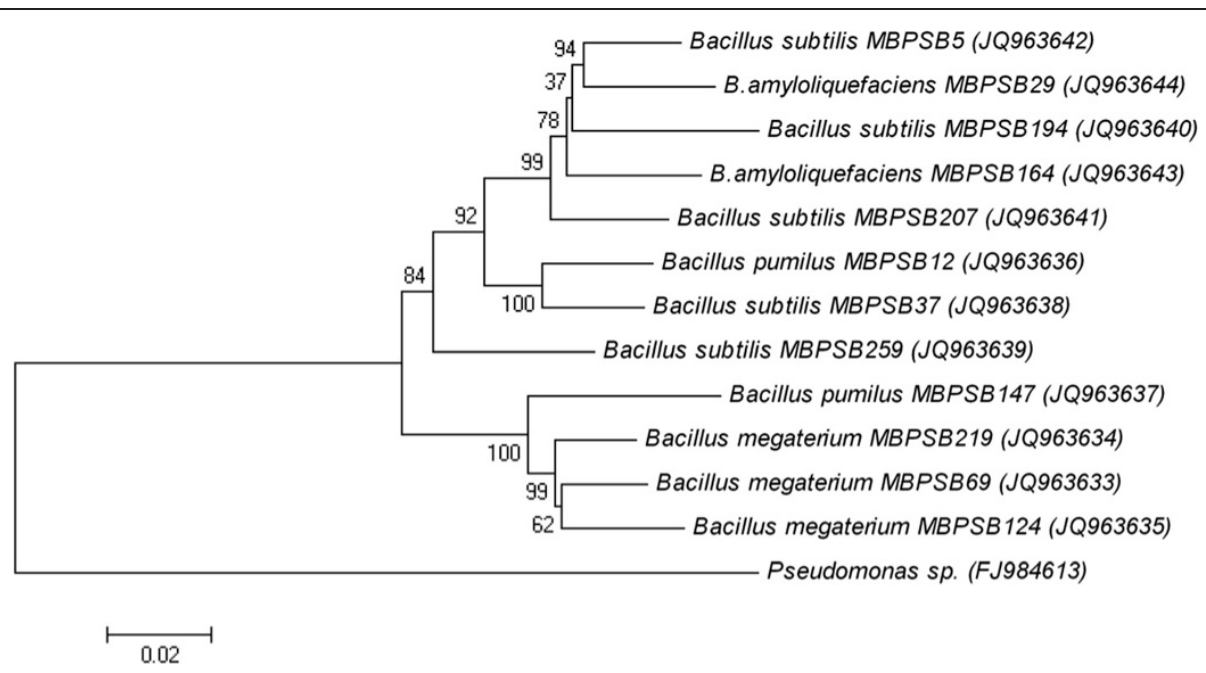

Figure 2 Phylogenetic tree of indigenous members of the genus Bacillus, based on 16S rRNA gene sequences. (Scale bar, 0.02 substitutions per nucleotide position). 

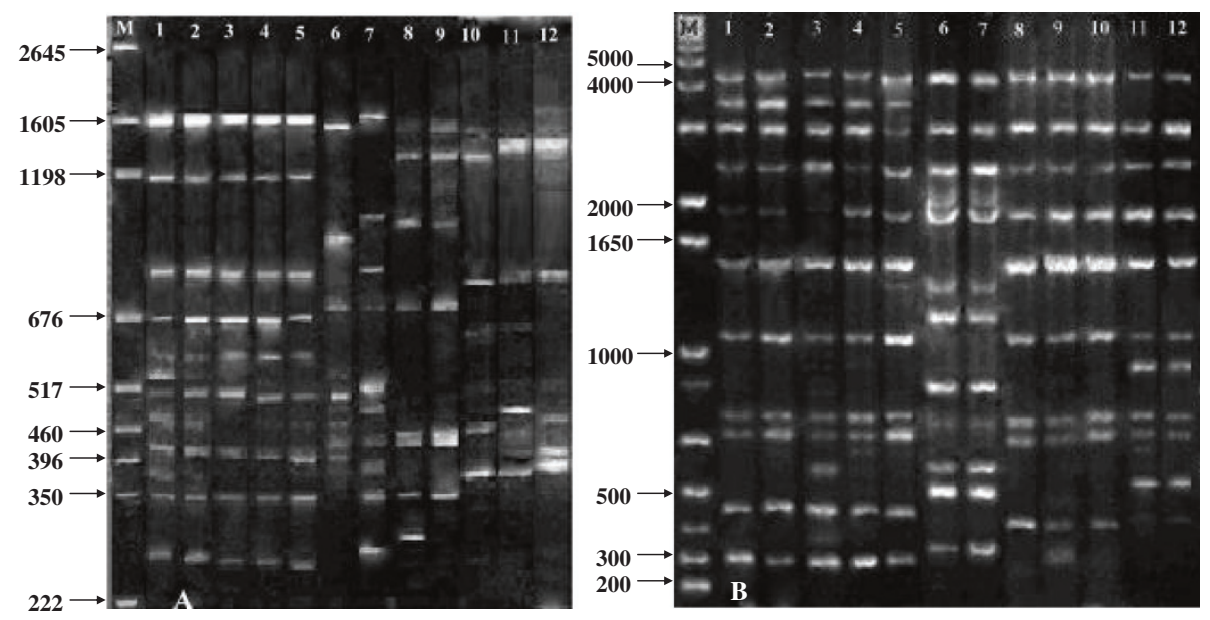

Figure 3 DNA fingerprinting patterns of indigenous isolates generated by (A) ERIC-PCR (B) BOX-PCR.

BOX-PCR) is excellent and reliable tools to characterize isolates at the genomic level.

\section{P-solubilization under stress conditions}

The stressful conditions prevailing in the soil have direct effect on the survival and proliferation of the soil microbiota (Miller and Woods 1996; Zahran 1999; Fierer and Jackson 2006). The most efficient isolate MBPSB 207 was further tested for phosphate (P) solubilization under stress conditions. As evident from Table 4 that at $5^{\text {th }}$ day of incubation, the highest P-solubilization was observed at temperature $37^{\circ} \mathrm{C}(831.72 \mu \mathrm{g} / \mathrm{ml})$ which was significantly higher than the other tested stress followed by $\mathrm{pH} 6.5(817.38 \mu \mathrm{g} / \mathrm{ml})$. The highest reduction in $\mathrm{P}$ solubilization was occurred at temperature of $15^{\circ} \mathrm{C}$ $(583.63 \mu \mathrm{g} / \mathrm{ml})$, followed by $\mathrm{pH} 9(597.01 \mu \mathrm{g} / \mathrm{ml})$ at $5^{\text {th }}$ day of incubation. Overall, the isolate MBPSB 207 survived well under different stress conditions and solubilized insoluble phosphorus. The high stress tolerance capacity of the tested isolate to different stress conditions indicated that biochemical and molecular system help the bacteria to adapt to these stressful conditions. The screening of stress-tolerant strain could be an important attribute in selection of indigenous strains for developing microbial inoculants to be used as biofertilizer for sustainable agriculture.

\section{Conclusions}

In summary, the present study have generated very useful information regarding genetic variability in plant growth promoting Bacillus strains which are also tolerant to various stress like temperature, $\mathrm{pH}$ and salinity. These results are very informative regarding development of bioinoculants for sustainable agriculture especially for increasing maize crop production and also this isolate (MBPSB 207) work efficiently under different stress conditions. But, further studies are required to check the potential and performance of these isolates under different field conditions. The studied isolates were categorized into four groups: B. amyloliquefaciens, B. megaterium, B. pumilus and B. subtilis depending on molecular characterization. Even though polyphasic technique was used to identify the Bacillus isolates but this approach was unable to discriminate the isolates at species level. Although, these strains were isolated from the same environmental source but they showed heterogeneity in their phenotypic and genetic characters.

Table 4 P-solubilization by most efficient isolate (MBPSB 207) under different stress conditions

\begin{tabular}{|c|c|c|c|c|c|}
\hline \multicolumn{6}{|c|}{ P-solubilization $(\mu \mathrm{g} / \mathrm{ml})$} \\
\hline \multirow[t]{2}{*}{ Stress } & \multicolumn{4}{|c|}{ Days of incubation } & \multirow[t]{2}{*}{ Mean } \\
\hline & 3 & 5 & 7 & 11 & \\
\hline $\mathrm{NaCl} 3.5 \%$ & 298.77 & 623.33 & 524.88 & 417.86 & 466.21 \\
\hline $\mathrm{NaCl} 7 \%$ & 302.53 & 712.49 & 602.97 & 514.67 & 533.17 \\
\hline pH 5.5 & 324.71 & 783.46 & 563.62 & 459.52 & 532.83 \\
\hline pH 6.5 & 391.55 & 817.38 & 616.35 & 524.51 & 587.45 \\
\hline $\mathrm{pH} 7.5$ & 339.64 & 746.29 & 509.82 & 442.6 & 509.59 \\
\hline pH 9 & 216.18 & 597.01 & 412.43 & 305.40 & 382.75 \\
\hline Tem $15^{\circ} \mathrm{C}$ & 302.58 & 583.63 & 463.90 & 375.52 & 431.41 \\
\hline Temp $37^{\circ} \mathrm{C}$ & 395.41 & 831.72 & 661.49 & 518.61 & 601.81 \\
\hline Mean & 321.42 & 711.91 & 544.43 & 444.84 & \\
\hline Variants & SEm \pm & $C D(p \leq 0.01)$ & & & \\
\hline Days & 0.35 & 1.72 & & & \\
\hline Stress & 0.5 & 2.44 & & & \\
\hline Interactions & 1 & 4.88 & & & \\
\hline
\end{tabular}




\section{Methods}

\section{Sampling and bacterial isolates}

Soil samples were collected from the rhizosphere of Malus domestica (Apple) growing in orchid at Theog, Shimla (India) at an elevation of about $2397 \mathrm{~m}$ above mean sea level and soil samples were heated at $80 \pm 1^{\circ} \mathrm{C}$ for $10 \mathrm{~min}$ before use. Tryptic soy agar was used for the isolation of bacterial strains by serial soil dilution technique and plates were incubated at $30 \pm 1^{\circ} \mathrm{C}$. The colonies obtained were purified by restreaking and stocked for further studies.

\section{Screening of efficient phosphate-solubilizing isolates}

The bacterial isolates were spot inoculated on PVK agar plates and the halo zones formed around the colony was measured after regular interval of times at $30 \pm 1^{\circ} \mathrm{C}$ ). For quantitative estimation of phosphate solubilization, NBRIP broth (containing 0.5\% TCP) was inoculated with screened isolates as described earlier by Nautiyal (1999) and vanado-molybdate method was used for the estimation of solubilized phosphorus (Jackson 1973). Alternative to TCP, iron phosphate, aluminium phosphate and hydroxyapatite were also tested at the rate of $0.5 \%$ for qualitative and quantitative analysis of most efficient isolates screened on TCP as described above.

\section{PGP characteristics of the bacteria}

\section{Indole-3-acetic acid (IAA) production}

For IAA production assay, bacterial cultures were grown until stationary phase in Luria-Bartani medium (LB) supplemented with $5 \mathrm{mM}$ L-tryptophan (Sigma) at $30 \pm$ $1^{\circ} \mathrm{C}$ in an orbital shaker at $100 \mathrm{rpm}$. Cell free supernatant was used to estimate the IAA by following the method of Gordon and Weber (1951).

\section{Siderophore production}

The agar plates containing Chrom Azurol S (CAS) dye was used for the detection of siderophore production (Schwyn and Neilands 1987). Colonies showing orange halos around them were considered as siderophore producer.

\section{Ammonia production}

For the detection of ammonia production organism was grown in $5 \mathrm{ml}$ of peptone water for $48-72 \mathrm{hrs}$ at $30 \pm 1^{\circ} \mathrm{C}$. After incubation $1 \mathrm{ml}$ of Nessler's reagent was added to inoculated peptone water and development of faint yellow to dark brown color indicate the production of ammonia (Bakker and Schippers 1987).

\section{Screening of bacterial isolates for antagonistic activity}

To determine antagonistic activity of the isolates against fungal pathogens Rhizoctonia solani and Fusarium oxysporum (obtained from Dept. of Microbiology, CSK HPKV,
Palampur, India), dual culture technique was used. For this, $96 \mathrm{hrs}$ old culture of fungus was used. Agar block of $5 \mathrm{~mm}$ diameter was spot inoculated at the centre of the agar plate and tested bacterial isolate was spot inoculated $2 \mathrm{~cm}$ away from the fungal culture. The plates were incubated at $30 \pm$ $1^{\circ} \mathrm{C}$ for $96 \mathrm{hrs}$ and checked for the antagonistic activity after 96 hrs.

\section{Enzyme tests}

\section{(i) Protease}

The screened isolates were spot inoculated on skim milk agar and plates were incubated at $30 \pm 1^{\circ} \mathrm{C}$ for $96 \mathrm{hrs}$. The isolate showing clear zone around the colony was considered as protease producer.

(ii) Chitinase The chitin agar medium plates were spot inoculated with log phase screened Bacillus cultures and plates were incubated at $30^{\circ} \pm 1^{\circ} \mathrm{C}$ for $96 \mathrm{hrs}$. The clear zone around the colony was considered as chitinase producer.

(iii) Cellulase

The cellulolytic activity was determined on Carboxymethyl cellulose (CMC) agar medium containing 1\% CMC as described earlier by Ariffin et al. (2006).

\section{Assay of 1-aminocyclopropane-1-carboxylate deaminase (ACCD)}

In different samples the absorbance of $\alpha$-ketobutyrate generated by the hydrolysis of 1-aminocyclopropane-1carboxylate $(\mathrm{ACC})$ by the enzyme ACC deaminase in the cell free extract was compared at $540 \mathrm{~nm}$ by using $\alpha$-ketobutyrate as a standard ranging between 0.1 and $1.0 \mu \mathrm{mol}$ (Saleh and Glick 2001; Penrose and Glick 2003). For ACCD activity bacteria was grown, centrifuged at $8000 \mathrm{rpm}$ and cell pellet was washed with Dworkin and Foster (DF) mineral medium and resuspended in $7.5 \mathrm{ml}$ of DF containing $3 \mathrm{mM} \mathrm{ACC}$. The inoculated DF medium was incubated at $30 \pm 1^{\circ} \mathrm{C}$ for one day, centrifuged and resuspended in $1 \mathrm{ml}$ of $0.1 \mathrm{M}$ Tris$\mathrm{HCl}$ buffer ( $\mathrm{pH} 7.6)$ and centrifuged at $8000 \mathrm{rpm}$ for 15 minutes. Then $600 \mu \mathrm{l}$ of $0.1 \mathrm{M}$ Tris- $\mathrm{HCl}$ buffer $(\mathrm{pH} 8.5)$ was added to the pellet, vortex and finally $30 \mu \mathrm{l}$ of toluene was added. The quantity of $\alpha$-ketobutyrate produced in the cell free suspension was used for the quantification. The solution containing no cell suspension or no ACC were used as controls.

\section{Seed germination bioassay}

In-vitro seed germination assay was conducted using twelve efficient PGPR isolates by soft agar plate method on Zea mays (maize) seeds. The bacterial cultures were grown in Tryptic soy broth, centrifuged, washed with 
sterilized phosphate buffer saline (PBS) and finally suspended in the sterilized PBS until the population reaches to $10^{8}$ cells per $\mathrm{ml}$. Before in-vitro testing, the surface of seed was sterilized as described earlier by JohnstonMonje and Raizada (2011). The seeds were dipped in bacterial cultures for 20 minutes and then placed in the soft agar plate containing $0.8 \%$ sterilized agar. The plates were incubated at $28 \pm 1^{\circ} \mathrm{C}$ for 3-5 days and seeds were observed for hypocotyl length and root length. By using the following formula the vigor index (VI) was calculated: (mean hypocotyl length + mean root length) $\mathrm{x} \%$ germination.

\section{PCR amplification and sequencing of genes encoding ACC deaminase (acdS genes) in Bacillus}

Partial acdS genes were amplified by using primers Deg ACCf (5'-GGBGGVAAYAARMYVMGSAAGCTYGA-3') and Deg ACCr (5'-TTDCCHKYRTANACBGGRTC-3') as described by Nikolic et al. (2011). PCR amplification was done using reaction mixture containing $20 \mathrm{ng}$ of DNA sample, $20 \mu \mathrm{M}$ dNTPs, 4 pmol of each primer, $2 \mathrm{mM} \mathrm{MgCl}_{2}$ and $1 \mathrm{U} \mathrm{Taq}$ polymerase under following conditions: initial denaturation for $5 \mathrm{~min}$ at $95^{\circ} \mathrm{C}$, followed by 30 cycles of denaturation for $37 \mathrm{sec}$ at $95^{\circ} \mathrm{C}$, annealing for $34 \mathrm{sec}$ at $55^{\circ} \mathrm{C}$, and elongation for $1 \mathrm{~min}$ at $72^{\circ} \mathrm{C}$ and then a final $5 \mathrm{~min}$ elongation at $72^{\circ} \mathrm{C}$. The purified product was sent for custom sequencing.

\section{Phenotypic characterization of bacterial isolates}

Morphological and biochemical characteristics of the efficient bacterial isolates were studied by the methods described in Bergey's Manual of Systematic Bacteriology (Holt et al. 1994).

\section{Sequence analysis of $16 \mathrm{~S}$ rDNA}

Genomic DNA of isolates was extracted by using QIAamp DNA Mini Kit (Qiagen, Valencia, CA) by following the manufacturer instructions. The primers used for $16 \mathrm{~S}$ rDNA amplification were $27 \mathrm{~F}$ (5'-AGAGTTT GATCCTGGCTCAG-3') and 1492R (5'-GGTTACCTTG TTACGACTT-3') (Meier et al. 2012). The thermo cycling conditions consisted of an initial denaturation step at $94^{\circ} \mathrm{C}$ for $5 \mathrm{~min}$, followed by 33 cycles of $94^{\circ} \mathrm{C}$ for $1 \mathrm{~min}, 52^{\circ} \mathrm{C}$ for $1 \mathrm{~min}$, and $72^{\circ} \mathrm{C}$ for $2 \mathrm{~min}$, and final extension at $72^{\circ} \mathrm{C}$ for $5 \mathrm{~min}$. The gel purified 16S rDNA was sent for custom sequencing. The phylogenetic tree was constructed by MEGA 3.1 using the NeighborJoining (N-J) method. The robustness of the phylogenetic tree topology was evaluated with 1000 replicates of bootstrap analysis.

\section{rep-PCR DNA fingerprinting}

The genomic fingerprinting of efficient strains was subjected to two types of rep-PCR using the BOX primer
(Versalovic et al. 1994) and ERIC primer (Versalovic et al. 1991). The ERIC primer i.e. ERIC1R (5'-ATG TAAGCTCCTGGGGATTCAC-3') and ERIC2 (5'-AAG TAAGTGACTGGGGTGAGCG-3') whereas BOXA1R (5'-CTACGGCAAGGCGACGCTGACG-3') were used for the amplification cycling of the rep-PCR. The amplified products were resolved by electrophoresis in 1.5\% agarose containing ethidium bromide $(0.5 \mu \mathrm{g} / \mathrm{ml})$ for $2.5 \mathrm{~h}$ at $80 \mathrm{~V}$. The fingerprints were visually compared.

\section{Phosphate solubilization under stress conditions}

The most efficient bacterial isolate was subjected to various stress parameters like $\mathrm{pH}(5.5,6.5,7.5$ and 9.0), temperature $\left(15^{\circ} \mathrm{C}\right.$ and $\left.37^{\circ} \mathrm{C}\right)$ and sodium chloride concentration $(3.5 \%$ and 7.0\%) in NBRIP broth and phosphate solubilized was quantified as discussed earlier. The uninoculated sterilized medium served as control.

\section{Statistical analysis}

The software STATISTICA version 7 (StatSoft ${ }^{\circ}$ Inc. Tulsa, USA) was used on present study data for the ANOVA and all the experiments were done in triplicates.

\section{Submission of gene sequences}

DNA sequences: The $16 \mathrm{~S}$ rDNA partial sequences of phosphate-solubilizing Bacillus spp. were deposited in the GenBank database under the accession numbers: JQ963633 (MBPSB 69), JQ963634 (MBPSB 219), JQ963635 (MB PSB 124), JQ963636 (MBPSB 12), JQ963637 (MBPSB 147), JQ963638 (MBPSB 37), JQ963639 (MBPSB 259), JQ963640 (MBPSB 194), JQ963641 (MBPSB 207), JQ96 3642 (MBPSB 5), JQ963643 (MBPSB 164), and JQ96 3644. (MBPSB 29).

The acdS gene partial sequence of most efficient isolate MBPSB 207 was deposited in the GenBank database under accession number JQ995371.

\section{Competing interests}

The authors declare that they have no competing interests.

\section{Author's contributions}

AJK design the research work, performed molecular biology work \& some PGPR tests, drafted the manuscript. AMK isolate the organisms and performed PGPR tests. AMP performed enzyme tests and helped in drafting the manuscript. All the authors read and approved the final manuscript.

\section{Acknowledgments}

Authors are thankful to President and Director, SILB, Solan (H.P), India for providing necessary facilities for the present research work. We are also very thankful to Prof. MP Vohra for their help and encouragement.

\section{Author details}

${ }^{1}$ Department of Microbiology, Shoolini Institute of Life Sciences and Business Management, Solan, Himachal Pradesh 173212, India. ${ }^{2}$ School of Biotechnology, Shoolini University, Solan, Himachal Pradesh 173212, India. ${ }^{3}$ Department of Biotechnology, Shoolini Institute of Life Sciences and Business Management, Solan, Himachal Pradesh 173212, India.

Received: 13 March 2014 Accepted: 18 June 2014

Published: 25 June 2014 


\section{References}

Ariffin H, Abdullah N, Umi Kalsom MS, Shirai Y, Hassan MA (2006) Production and characterization of cellulose by Bacillus pumilus FB3. Int J Eng Tech 3:47-53

Bakker AW, Schippers P (1987) Microbial cyanide production in the rhizosphere in relation to potato yield reduction and Pseudomonas spp.-mediated plant growth-stimulation. Soil Biol Biochem 19:451-457

Bakker PAHM, Berendsen RL, Doornbos RF, Wintermans PCA, Pieterse CMJ (2013) The rhizosphere revisited: root microbiomics. Front Plant Sci 4:165

Bashan Y, Kamnev AA, De-Bashan LE (2013) Tricalcium phosphate is inappropriate as a universal selection factor for isolating and testing phosphate-solubilizing bacteria that enhance plant growth: a proposal for an alternative procedure. Biol Fertil Soils 49:465-479

Belimov AA, Safronova VI, Sergeyeva TA, Egorova TN, Matveyeva VA, Tsyganov VE, Borisov AY, Tikhonovich IA, Kluge C, Preisfeld A, Dietz KJ, Stepanovik W (2001) Characterization of plant growth promoting rhizobacteria isolated from polluted soils and containing 1-aminocyclopropane-1-carboxylate deaminase. Can J Microbiol 47:642-652

Benizri E, Courtade A, Picard C, Guckert A (1998) Role of maize root exudates in the production of auxins by Pseudomonas fluorescens M.3.1. Soil Biol Biochem 30:1481-1484

Bhandari V, Ahmod NZ, Shah HN, Gupta RS (2013) Molecular signatures for the Bacillus species: Demarcation of the Bacillus subtilis and Bacillus cereus clades in molecular terms and proposal to limit the placement of new species into the genus Bacillus. Int J Syst Evol Microbiol 63:2712-2726

Chudzik KB, Stosik M (2005) Specific genomic fingerprints of Escherichia coli strains with Repetitive sequences and PCR as an effective tool for monitoring freshwater environments. Pol J Environ Stud 14:551-557

Duca D, Lorv J, Patten CL, Rose D, Glick BR (2014) Indole-3-Acetic Acid in PlantMicrobe Interactions. Antonie Van Leeuwenhoek, in press

Farina R, Beneduzi A, Ambrosini A, de Campos SB, Lisboa BB, Wendisch V, Vargas LK, Passaglia LMP (2012) Diversity of plant growth-promoting rhizobacteria communities associated with the stages of canola growth. Appl Soil Ecol 55:44-52

Fgaier H, Eberl HJ (2011) Antagonistic control of microbial pathogens under iron limitations by siderophore producing bacteria in a chemostat setup. J Theor Biol 273:103-114

Fierer F, Jackson RB (2006) The diversity and biogeography of soil bacterial communities. Proc Natl Acad Sci U S A 103:626-631

Gholami A, Shahsavani S, Nezarat S (2009) The effect of Plant Growth Promoting Rhizobacteria (PGPR) on germination, seedling growth and yield of Maize. World Acad Sci Eng Technol 49:19-24

Glick BR (1995) The enhancement of plant growth by free-living bacteria. Can J Microbiol 41:109-117

Glick BR (2014) Bacteria with ACC deaminase can promote plant growth and help to feed the world. Microbiol Res 169:30-39

Gordon SA, Weber RP (1951) Colorimetric estimation of indoleacetic acid. Plant Physiol 26:192-195

Hahn HK, Strittmatter HK (1994) Pathogen-defense gene prp1-1 from potato encodes an auxin-responsive glutathione-s-transferase. Eur J Biochem 226:619-626

Harrel LJ, Anderson GL, Wilson KH (1995) Genetic variability of Bacillus anthracis and related species. J Clin Microbiol 33:1847-1850

Hayat R, Ali S, Amara U, Khalid R, Ahmed I (2010) Soil beneficial bacteria and their role in plant growth promotion: a review. Ann Microbiol 60:579-598

Holt JG, Kreig NR, Sneath PHA, Stanley JT, Williams ST (1994) Bergey's Manual of Determinative Bacteriology. Williams and Wilkins, Baltimore, USA

Ishii S, Sadowsky MJ (2009) Applications of the rep-PCR DNA fingerprinting technique to study microbial diversity, ecology and evolution. Environ Microbiol 11:733-740

Jackson ML (1973) Soil Chemical Analysis. Prentice Hall of India Pvt. Ltd, New Delhi

Janda JM, Abbott SL (2007) 16 S rRNA Gene sequencing for bacterial identification in the diagnostic laboratory: Pluses. Perils, and Pitfalls, J Clin Microbiol 45:2761-2764

Johnston-Monje D, Raizada MN (2011) Conservation and diversity of seed associated endophytes in Zea across boundaries of evolution, ethnography and ecology. PLoS One 6:e20396

Kim W, Song MO, Song W, Kim KJ, Chung SI, Choi CS, Park YH (2003) Comparison of $165 \mathrm{rDNA}$ analysis and rep-PCR genomic fingerprinting for molecular identification of Yersinia pseudotuberculosis. Antonie Van Leeuwenhoek 83:125-133
Krakova L, Chovanova K, Selim SA, Simonovicova A, Puskarova A, Makova A, Pangallo D (2012) A multiphasic approach for investigation of the microbial diversity and its biodegradative abilities in historical paper and parchment documents. Int Biodeter Biodegr 70:117-125

Mano Y, Nemoto K (2012) The pathway of auxin biosynthesis in plants. J Exp Bot 63:2853-2872

Meier J, Piva A, Fortin D (2012) Enrichment of sulfate-reducing bacteria and resulting mineral formation in media mimicking pore water metal ion concentrations and $\mathrm{pH}$ conditions of acidic pit lakes. FEMS Microbiol Ecol 79:69-84

Mia MAB, Shamsuddin ZH, Mahmood M (2012) Effects of rhizobia and plant growth promoting bacteria inoculation on germination and seedling vigor of lowland rice. Afr J Biotechnol 11:3758-3765

Miller KJ, Woods JR (1996) Osmoadaptation by rhizosphere bacteria. Annu Rev Microbiol 50:101-136

Miransari M, Smith DL (2014) Plant hormones and seed germination. Environ Exp Bot 99:110-121

Nautiyal CS (1999) An efficient microbiological growth medium for screening phosphate solubilizing microorganisms. FEMS Microbiol Lett 170:265-270

Nikolic B, Schwab H, Sessitsch A (2011) Metagenomic analysis of the 1aminocyclopropane-1-carboxylate deaminase gene (acdS) operon of an uncultured bacterial endophyte colonizing Solanum tuberosum L. Arch Microbiol 193:665-676

Patil HJ, Srivastava AK, Kumar S, Chaudhari BL, Arora DK (2010) Selective isolation, evaluation and characterization of antagonistic Actinomycetes against Rhizoctonia solani. World J Microbiol Biotechnol 26:2163-2170

Peleg Z, Blumwald E (2011) Hormone balance and abiotic stress tolerance in crop plants. Curr Opin Plant Biol 14:290-295

Penrose DM, Glick BR (2003) Methods for isolating and characterizing ACC deaminase-containing plant growth-promoting rhizobacteria. Physiol Plantarum 118:10-15

Rademaker JLW, Aarts HJM, Vinuesa P (2005) Molecular typing of environmental isolates. In: Osborn AM, Smith CJ (eds) Molecular Microbial Ecology. Taylor and Francis Group, US, pp 97-131

Rodriguez H, Fraga R (1999) Phosphate solubilizing bacteria and their role in plant growth promotion. Biotechnol Adv 17:319-339

Saleh SS, Glick BR (2001) Involvement of gasS and proS in enhancement of the plant growth-promoting capabilities of Enterobacter cloacae CAL2 and UW4. Can J Microbiol 47:698-705

Saraf M, Jha CK, Patel D (2011) The Role of ACC Deaminase Producing PGPR in Sustainable Agriculture. In: Maheshwari DK (ed) Plant Growth and Health Promoting Bacteria Microbiology, Monographs vol. 18, series editor Steinbuchel A. Springer, Germany, pp 365-386

Schwyn B, Neilands JB (1987) Universal chemical assay for detection and determination of siderophore. Analytical Biochem 160:47-56

Sharma SB, Sayyed RZ, Trivedi MH, Gobi TA (2013) Phosphate solubilizing microbes: sustainable approach for managing phosphorus deficiency in agricultural soils. SpringerPlus 2:587

Sulbaran M, Perez E, Ball MM, Bahsas A, Yarzabal LA (2009) Characterization of the mineral phosphate-solubilizing activity of Pantoea aglomerans MMB051 isolated from an iron-rich soil in southeastern Venezuela (Bolivar state). Curr Microbiol 58:378-383

Tripura C, Sashidhar B, Podile AR (2007) Ethyl methanesulfonate mutagenesis-enhanced mineral phosphate solubilization by groundnutassociated Serratia marcescens GPS-5. Curr Microbiol 54:79-84

Tsavkelova EA, Klimova SY, Cherdyntseva TA, Netrusov Al (2006) Microbial producers of plant growth stimulators and their practical use: A Review. Appl Biochem Microbiol 42:117-126

Versalovic J, Koeuth T, Lupski JR (1991) Distribution of repetitive DNA sequences in eubacteria and application to fingerprinting of bacterial genomes. Nucleic Acids Res 19:6823-6831

Versalovic J, Schneider M, De Bruijn FJ, Lupski JR (1994) Genomic fingerprinting of bacteria using repetitive sequence-based polymerase chain reaction. Meth Mol Cell Biol 5:25-40

Versalovic J, de Bruijn FJ, Lupski JR (1998) Repetitive Sequence-based PCR (rep-PCR) DNA Fingerprinting of Bacterial Genomes. In: Bruijn FJ, Lupski JR, Weinstock GM (eds) Bacterial Genomes: Physical Structure and Analysis. Springer, USA, pp 437-454

Vriezen JAC, de Bruijn FJ, Nusslein K (2006) Desiccation responses and survival of Sinorhizobium meliloti USDA 1021 in relation to growth phase, 
temperature, chloride and sulphate availability. Lett Appl Microbiol 42:172-178

Weisburg WG, Barns SM, Pelletier DA, Lane DJ (1991) 165 ribosomal DNA amplification for phylogenetic study. J Bacteriol 173:697-703

Zahran HH (1999) Rhizobium legume symbiosis and nitrogen fixation under severe conditions and in arid climate. Microbiol Mol Biol Rev 63:968-989

Zelicourt A, Al-Yousif M, Hirt H (2013) Rhizosphere microbes as essential partners for plant stress tolerance. Mol Plant 6:242-245

doi:10.1186/2193-1801-3-312

Cite this article as: Kumar et al:: Molecular diversity and functional variability of environmental isolates of Bacillus species. SpringerPlus 2014 3:312.

\section{Submit your manuscript to a SpringerOpen ${ }^{\circ}$ journal and benefit from:}

- Convenient online submission

- Rigorous peer review

- Immediate publication on acceptance

- Open access: articles freely available online

- High visibility within the field

- Retaining the copyright to your article 